\title{
The Mode of Action of $N$-(n-Dodecyl)diethanolamine with Particular Reference to the Effect of Protonation on Uptake by Escherichia coli
}

\author{
By P. A. LAMBERT* AND A. R. W. SMITH \\ School of Biological Sciences, Thames Polytechnic, London SEI8 6PF
}

(Received 28 July 1977)

\begin{abstract}
In a homologous series of $N$-(n-alkyl)diethanolamines antimicrobial activity was related to surface activity and increasing octanol-water partition coefficient. Maximum activity was exhibited by the dodecyl-, tetradecyl- and hexadecyl-derivatives. Dodecyldiethanolamine (DDE) displayed a broad spectrum of activity. Towards Escherichia coli NCIB8277, its bacteriostatic and bactericidal activity increased as the degree of protonation lessened, and may have been influenced by the formation of micelles. Uptake of DDE by washed suspensions of $E$. coli was more rapid and more extensive at $\mathrm{pH} 7 \cdot 0$ than $\mathrm{pH} 4^{\circ} \mathrm{O}$. Within this $\mathrm{pH}$ range, bacterial uptake, the octanol-water partition coefficient (lipid solubility) and the proportion of unprotonated DDE all increased. Uptake isotherms at $\mathrm{pH}$ values in the range 4.0 to 8.0 are interpreted as signifying different uptake mechanisms for the protonated and unprotonated forms.
\end{abstract}

\section{INTRODUCTION}

$N$-(n-dodecyl)diethanolamine (DDE) is bacteriostatic and bactericidal towards Escherichia coli. We have previously shown (Lambert \& Smith, 1976) that at $\mathrm{pH} 7 \cdot 0 \mathrm{DDE}$ was taken up by whole cells in less than $3 \mathrm{~min}$, resulting in the rapid leakage of potassium ions and the cessation of glucose oxidation. Sphaeroplast suspensions in isotonic media were destabilized. Nucleotide leakage from whole cells was biphasic, corresponding to an initial loss of low molecular weight pool metabolites (within Io min) followed by slower efflux of rRNA breakdown products (extending over $3 \mathrm{~h}$ ) due to the drug-induced activation of latent RNAase I activity (Lambert \& Smith, 1977).

These observations support the conclusion that DDE is a membrane-active (Hamilton, 1971) antimicrobial agent. In the present paper we compare the antimicrobial activity of homologous $N$-( $n$-alkyl)diethanolamines and describe the effect of $\mathrm{pH}$ on the activity and uptake of DDE. A preliminary report of this investigation has appeared (Lambert \& Smith, 1974). No other publications have been found that refer to the antimicrobial activity of the alkyldiethanolamines, although Persianov et al. (1968) have demonstrated antimicrobial properties towards E. coli and Staphylococcus aureus in the related alkoxydiethanolamines.

\section{METHODS}

Chemicals. We thank Drs W. Mann and B. Demetriou of the School of Chemistry for the synthesis and purification of alkyldiethanolamines. Members of the series $N$ - $(n$-methyl)diethanolamine to $N$ - $(n$-octadecyl)diethanolamine were synthesized by standard methods (Hanby \& Rydon, 1947). Thus, methyl-

* Present address: Microbiological Chemistry Research Laboratory, School of Chemistry, The University, Newcastle-upon-Tyne NEI 7 RU. 
diethanolamine was prepared from diethanolamine by the Clarke-Eschweiler procedure; higher homologues were obtained by alkylation of diethanolamine with the corresponding alkylbromide in the presence of potassium carbonate. The products were extracted with acetone and purified by recrystallization or distillation under reduced pressure. The purity of each derivative was assessed by thin-layer chromatography and by equivalent weight determination. Identity was confirmed by nuclear magnetic resonance and infrared spectroscopy.

Assay of alkyldiethanolamines. Alkyldiethanolamines were determined by the dye complex procedure of Scott (1968) using Orange II (BDH). Separate calibration curves were prepared for each compound.

Buffers. Sodium 3,3'-dimethylglutarate (DMG) buffer and sodium acetate buffer were used at $0.1 \mathrm{M}$ as described by Dawson et al. (1969).

Octanol-water partition coefficients. Portions $(5 \mathrm{ml})$ of a $1.0 \mathrm{mM}$ solution of alkyldiethanolamine in water, adjusted to $\mathrm{pH} 7 \cdot 0$ with acetic acid, were shaken with equal volumes of octan-1-ol in sealed tubes for $48 \mathrm{~h}$ at $25^{\circ} \mathrm{C}$. The tubes were then centrifuged at $3000 \mathrm{~g}$ for $10 \mathrm{~min}$ to break the emulsion and the residual concentration of alkyldiethanolamine in the aqueous phase was measured after complexing with Orange II. The concentration in the octanol phase was calculated by difference. Octanol-water partition coefficients in the range $\mathrm{pH} 4.0$ to 8.0 were determined using DMG buffer in place of water.

Surface activity. Portions (Io $\mathrm{ml}$ ) of $10 \mathrm{mM}$-alkyldiethanolamine in DMG buffer $\mathrm{pH} 7.0$ were agitated for $5 \mathrm{~s}$ in stoppered $20 \mathrm{ml}$ tubes. Those compounds that produced a foam which remained stable after standing for 2 min were arbitrarily classified as possessing surface activity.

Critical micelle concentration of DDE. This was determined by dye titration (Corrin \& Harkins, 1947) using bromocresol purple and dichlorofluorescein at $\mathrm{pH}_{4} .6$ in acetate buffer and at $\mathrm{pH} 7 \cdot 0$ in DMG buffer using bromothymol blue and methyl red. All dyes were obtained from BDH.

Organisms. Escherichia coli NCIB8277, Pseudomonas aeruginosa NCIB8295, Bacillus subtilis NCIB36ro, Staphylococcus aureus NCIB657I, Streptococcus faecalis NCIB7432, Mycobacterium phlei NCIB8573 and Candida albicans NCTC71 3 were maintained by fortnightly subculture on slopes of nutrient agar (Oxoid). For growth of Strep. faecalis, a supplement of $0.5 \%(\mathrm{w} / \mathrm{v})$ glucose was always added. All cultures were grown at $37^{\circ} \mathrm{C}$.

Minimum inhibitory concentration (m.i.c.). This was determined in a final volume of $10 \mathrm{ml}$ in tubes of nutrient broth no. 2 (Oxoid) at pH 6.5, using an inoculum prepared from an overnight culture. Inocula were determined by total counting using a Neubauer chamber (Hawksley, London). After incubation for $24 \mathrm{~h}$, growth was assessed by visual inspection for turbidity. With amyl-, hexyl- and heptyldiethanolamine, which produced a turbid solution, growth was assessed by determining total counts as above.

The effect of $\mathrm{pH}$ on the m.i.c. was determined in a buffered glucose/minimal salts medium (Smith et al., 1975), adjusted to $\mathrm{pH}$ values between 6.0 and 8.0 with DMG.

Bactericidal activity of DDE. Nutrient broth $(200 \mathrm{ml})$ in $500 \mathrm{ml}$ Erlenmeyer flasks was inoculated with $E$. coli and incubated in shake culture in a water bath at $37^{\circ} \mathrm{C}$ for $14 \mathrm{~h}$. The bacteria (in late-exponential phase) were harvested by centrifugation, washed once in quarter-strength Ringer's solution and suspended in fresh solution at a density of $10^{3}$ organisms $\mathrm{ml}^{-1}$, counted in a Neubauer chamber. Ten ml of this suspension was filtered through a Millipore cellulose acetate membrane ( $47 \mathrm{~mm}$ diam.; $0.45 \mu \mathrm{m}$ pore size) and exposed to Io $\mathrm{ml}$ DDE solution in either DMG buffer $\mathrm{pH} 7 \cdot 0$, or acetate buffer $\mathrm{pH} 4 \cdot 6$. The solution was rapidly removed by suction and the bacteria were washed with $100 \mathrm{ml}$ quarter-strength Ringer's solution. Filters were incubated on nutrient agar plates and the resulting colonies were counted after $24 \mathrm{~h}$. This method controlled the drug-cell contact time within $\pm 5 \mathrm{~s}$.

Preparation of standardized suspensions and measurement of DDE uptake by E. coli. Bacteria were washed once in quarter-strength Ringer's solution and resuspended in DMG buffer to give an $E_{560 \mathrm{~mm}}^{1 \mathrm{~cm}}$ of $\mathrm{I} \cdot 0(\mathrm{I} \cdot 48$ $\mathrm{mg}$ dry wt $\mathrm{ml}^{-1}$ or $\mathrm{I} \cdot 8 \times \mathrm{IO}^{8}$ bacteria $\left.\mathrm{ml}^{-1}\right)$. These are referred to as standardized suspensions and were always diluted 9 to Io by addition of DDE solution.

To measure the rate of uptake of DDE, $10 \mathrm{ml}$ portions of suspension treated with DDE were rapidly filtered through Millipore membranes. Separation from the drug remaining in solution was achieved within Io $\mathrm{s}$. Residual DDE in the filtrate was assayed after complexing with Orange II and the uptake was calculated by difference. Uptake of the drug was essentially complete after 5 min contact; therefore, for measurements of equilibrium uptake, the bacteria were removed from suspension by centrifuging at $10000 \mathrm{~g}$ for $5 \mathrm{~min}$ using a type $\mathrm{SS}_{3}$ Servall bench centrifuge (Ivan Sorvall, Connecticut, U.S.A.).

Uptake of DDE by isolated E. coli envelopes and cytoplasm. Bacteria from $250 \mathrm{ml}$ of a standardized suspension were deposited by centrifuging at $10000 \mathrm{~g}$ for Io min, resuspended in $25 \mathrm{ml} \mathrm{DMG}$ buffer $\mathrm{pH} 7 \cdot 0$, and subjected to ultrasonic irradiation ( $20 \mathrm{kHz}, 6 \mu \mathrm{m}$ amplitude) for 20 min using an MSE ultrasonic disintegrator. Direct counting showed that fewer than $5 \%$ of the cells remained intact: these were then removed by centrifuging at $5000 \mathrm{~g}$ for $5 \mathrm{~min}$. Envelopes were collected by centrifuging the supernatant fluid at $10000 \mathrm{~g}$ for $20 \mathrm{~min}$, and were resuspended in $250 \mathrm{ml}$ DMG buffer. The supernatant fluid was likewise diluted to $250 \mathrm{ml}$. The two fractions were designated envelopes and cytoplasm respectively. 
Samples $(9 \mathrm{ml})$ of each of these fractions, together with a standardized suspension of unbroken bacteria, were treated with various concentrations of DDE for $5 \mathrm{~min}$ at $25^{\circ} \mathrm{C}$. With cytoplasm, a flocculent precipitate formed. After centrifuging at $10000 \mathrm{~g}$ for $20 \mathrm{~min}$, residual DDE in the supernatant fluids was measured after complexing with Orange II. It was not possible to distinguish between free dissolved DDE and that reversibly associated with soluble cytoplasmic material. An indication of the amount of cytoplasmic material removed as precipitate was obtained by measuring the absorbance of the soluble fraction at $260 \mathrm{~nm}$ after treatment with DDE.

Measurement of cellular and molecular dimensions. The average dimensions of $E$. coli were determined from electron micrographs, taken at a magnification of $80000 \times$ with an AEI model EM6B electron microscope, using conventional techniques of electron microscopy. The dimensions of the DDE molecule were determined by constructing a scale model from the Dreiding Molecular Model Kit (Koch-Light) as recommended by Fieser \& Fieser (1959) for accurate determination of dimensions with strict control of steric factors.

\section{RESULTS AND DISCUSSION}

\section{Antimicrobial activity of a homologous series of alkyldiethanolamines}

Appreciable antimicrobial activity against $E$. coli (m.i.c. $2 \mathrm{~mm}$ or less with inocula of $2 \times 10^{7}$ organisms $\mathrm{ml}^{-1}$ ) was exhibited only by those members of the series that displayed surface activity (heptyldiethanolamine and higher homologues), maximum activity being shared by the $\mathrm{C}_{12}, \mathrm{C}_{14}$ and $\mathrm{C}_{16}$ homologues with m.i.c. of $\mathrm{O} \cdot \mathrm{I} \mathrm{mM}$.

Alkyldiethanolamines therefore behave like the membrane-active (Hamilton, 197I) group of antimicrobial agents. As in other homologous series such as the $n$-alkylamines (Fuller, 1942; Cummings et al., 1953), and the alkyltrimethylammonium bromides (Shelton et al., 1946), the more potent homologues bear more than six but fewer than 18 carbon atoms in the alkyl chain, maximum potency within the series being displayed by those members bearing between 12 and 16 carbon atoms.

The antimicrobial activity of members above $\mathrm{C}_{7}$ also correlated with a rise in the octanolwater partition coefficient, although the values obtained did not conform to the principle of additivity (Hansch, Leo \& Nikaitani, 1972). In particular, the partition of the lower members was lower than expected, $\left(C_{7}, 0.8 ; C_{8}, I \cdot 9 ; C_{9}, 2.6 ; C_{10}\right.$ to $C_{18}, 3.3$ to 3.7$)$, but since determinations were carried out at $\mathrm{pH} 7 \cdot 0$, it is probable that the lower members were appreciably protonated and therefore more water-soluble.

\section{Studies on $D D E$}

Determinations of the m.i.c. of DDE towards other micro-organisms provided an indication of its spectrum of activity. Determinations were made with inocula of $10^{5}$ organisms $\mathrm{ml}^{-1}$, except for C. albicans $\left(2 \times \mathrm{ro}^{4}\right.$ organisms $\left.\mathrm{ml}^{-1}\right)$. With the not unexpected exception of $P$. aeruginosa (m.i.c. I mM), DDE displayed approximately equal potency (0.06 to $0.1 \mathrm{mM})$ towards all the bacteria tested. The lower m.i.c. for $C$. albicans $(0.02 \mathrm{~mm})$ was probably a consequence of the smaller inoculum employed. Dodecyldiethanolamine, in common with other membrane-active antimicrobial agents, therefore appears to have a wide spectrum of activity.

By titration, DDE was found to be a weak base with a pK of $6 \cdot 4$ : thus the extent of protonation diminished sharply from $99.99 \%$ at $\mathrm{pH} 4.0$ to $2 \%$ at $\mathrm{pH} 8 \cdot 0$. The apparent octanol-water partition coefficient increased correspondingly, though the difference between the values obtained at $\mathrm{pH} 8 \cdot 0(3 \cdot 8)$ and $4 \cdot 0(2 \cdot 0)$ was too small to be explained by the relationship between apparent partition and $\mathrm{pH}$ derived by Cymerman-Craig \& Diamantis (1953). Further work is required before an explanation can be offered for this effect.

The m.i.c. towards $E$. coli $\left(2 \times 10^{7}\right.$ organisms $\left.\mathrm{ml}^{-1}\right)$ decreased from $0.042 \mathrm{~mm}$ at $\mathrm{pH} 6 \cdot 0$ to $0.026 \mathrm{~mm}$ at $\mathrm{pH} 8.0$ (two experiments gave identical results using $0.002 \mathrm{~mm}$ steps), indicating that the free amine exerted greater inhibition than did the protonated species. In terms of the free amine concentration, the m.i.c. in the $\mathrm{pH}$ range $8 \cdot 0$ to 6.5 was roughly constant, therefore over this range it is most probable that inhibition of growth was due almost 


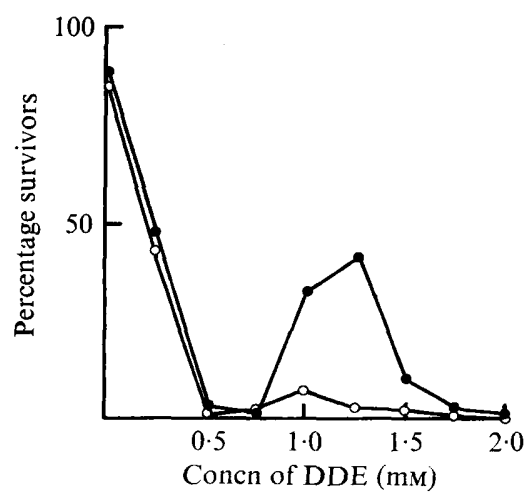

Fig. I

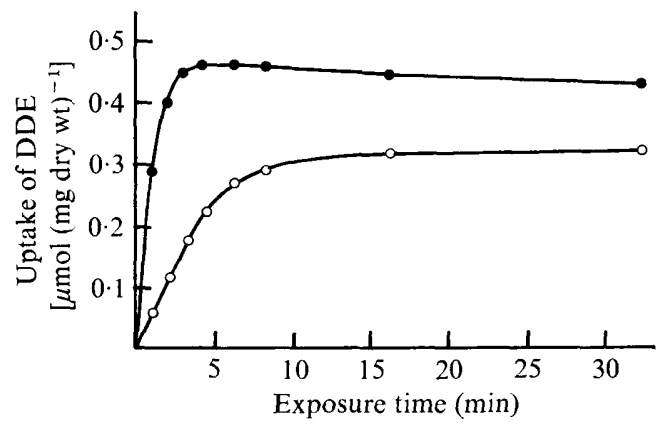

Fig. 2

Fig. I. Effect of $\mathrm{pH}$ on survival of $E$. coli exposed to DDE. Organisms (104) on Millipore membranes were exposed for I min to various concentrations of DDE: $0, \mathrm{pH} 4 \cdot 6 ; 0, \mathrm{pH} 7 \cdot 0$.

Fig. 2. Uptake of DDE at $\mathrm{pH}_{4} \circ \mathrm{O}(\mathrm{O})$ and $\mathrm{pH} 7 \cdot 0(O)$ by standardized suspensions of $E$. coli at $25^{\circ} \mathrm{C}$.

entirely to the free form of the amine. Between $\mathrm{pH} 6.5$ and 6.0 there was a sharp fall in the m.i.c. in terms of the free amine, suggesting the operation of a different mechanism of action, possibly involving the protonated species to a greater extent.

Although at both $\mathrm{pH} 4.6$ and 7.0 all organisms exposed to $0.5 \mathrm{mM}$-DDE were killed within $3 \mathrm{~min}$, the lethal effect of the free amine after I min was somewhat greater towards $E$. coli than that of the protonated species (Fig. I). At both $\mathrm{pH}$ values, death was progressively more rapid as the drug concentration was increased to $0.5 \mathrm{~mm}$; however, marked discontinuities were evident in both the survival curves over the concentration range 0.9 to $\mathrm{I} \cdot 8 \mathrm{mM}-\mathrm{DDE}$, with maxima exhibited at approx. $\mathrm{I} \cdot 0 \mathrm{mM}(\mathrm{pH} 7 \cdot 0)$ and approx. $\mathrm{I} \cdot 2 \mathrm{mM}$ ( $\mathrm{pH} \mathrm{4}$.6). The critical micelle concentrations (c.m.c.) of DDE, determined by the dye titration procedure, were $\mathrm{I} \cdot 0 \mathrm{mM}$ at $\mathrm{pH} 7.0$ (DMG buffer) and $\mathrm{I} .5 \mathrm{mM}$ at $\mathrm{pH} 4.6$ (acetate buffer). The decrease in bactericidal effectiveness at concentrations close to the c.m.c. may be attributable to micelle formation.

The ability of surface-active bactericides to bind rapidly and in large quantities to the surface of bacteria is important in their efficiency (Sykes, I965). Standardized suspensions of $E$. coli treated with 0.5 mM-DDE rapidly took up the drug at both $\mathrm{pH} 4.0$ and $7 \cdot 0$ (Fig. 2), and the process was essentially complete within $5 \mathrm{~min}$. The uptake was, however, greater in both rate and extent at $\mathrm{pH} 7 \cdot 0$ than at $\mathrm{pH} 4.0$, which suggested that the unprotonated amine was taken up more efficiently than was the protonated species and may account for the greater rate of kill by the free amine.

From uptake isotherms (equilibrium uptake plotted against concentration of the drug remaining in solution), it is possible to make useful deductions concerning the mechanisms involved in the sorptive process (Hugo, 1967 ). The isotherms at $\mathrm{pH} 4 \cdot 0,5^{\circ} \mathrm{O}$ and $6 \cdot 0$ (Fig. 3) all consisted of two curved phases, each concave to the concentration axis. Isotherms at $\mathrm{pH} 7.0$ and 8.0 were, by contrast, monophasic and convex to the concentration axis. At low drug concentrations, the first phase of isotherms in the range $\mathrm{pH}_{4} .0$ to 6.0 were Langmuirian. This form has been interpreted by Giles et al. (1960) as indicative of the adsorption of vertically orientated ions with particularly strong intermolecular attractions. The results therefore suggest the adsorption of protonated molecules, the predominant form in this $\mathrm{pH}$ range, to anionic binding sites on the cell surface. This configuration favours strong intermolecular attraction due to van der Waals' forces between the paraffinic dodecyl chains of adjacently bound molecules. The uptake of DDE in the plateau regions of these three isotherms was identical [0.1 $\mu \mathrm{mol}$ DDE (mg dry $\mathrm{wt}^{-1}{ }^{-1}$, and may have represented the 


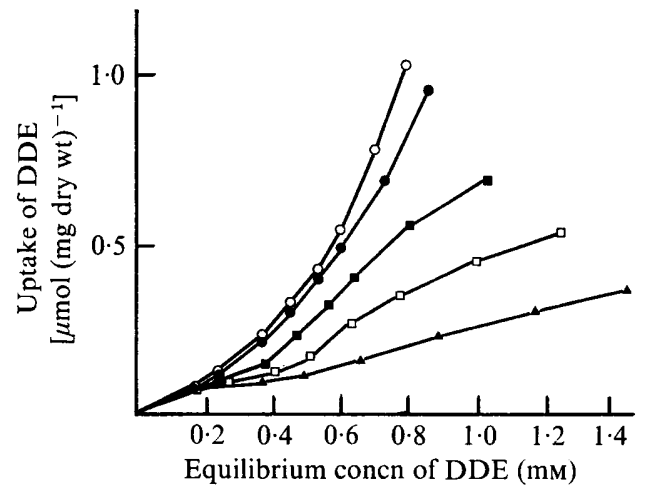

Fig. 3

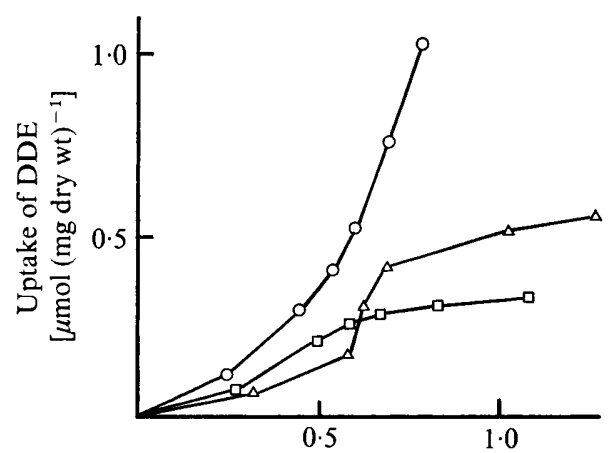

Equilibrium concn of DDE (mM)

Fig. 4

Fig. 3. Effect of pH and concentration of DDE on its uptake by standardized suspensions of $E$. coli

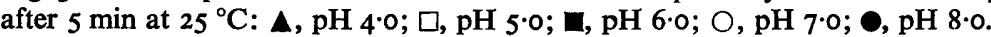

Fig. 4. Uptake of DDE after $5 \mathrm{~min}$ at $25^{\circ} \mathrm{C}$ and $\mathrm{pH} 7.0$ by standardized suspensions of whole bacteria and subcellular fractions of $E$. coli: $O$, whole bacteria; $\square$, bacterial envelopes; $\triangle$, cytoplasm.

adsorption of a monolayer of molecules to the surface of the bacteria. To test this hypothesis further, estimates of the area of the bacterial cell surface and of the cross-sectional area of the diethanolamine moiety were obtained. Using measurements taken from electron micrographs, the average $E$. coli bacterium was considered to consist of a cylinder of length $4.0 \mu \mathrm{m}$ and diameter $0.8 \mu \mathrm{m}$ surmounted by hemispheres of radius $0.4 \mu \mathrm{m}$ at each end, thus having a surface area of $12 \mu \mathrm{m}^{2}$. From a Dreiding scale model of DDE, the average crosssectional area of the diethanolamine moiety was $2.2 \times 10^{-7} \mu \mathrm{m}^{2}$. The formation of a monolayer of the type described therefore required $5.5 \times 10^{7}$ molecules cell ${ }^{-1}$, and the observed uptake was $5 \times 10^{7}$ molecules cell-1. The close agreement between these two values is consistent with the completion of a molecular monolayer around each cell.

Further uptake at higher concentrations took the form of a secondary Langmuirian phase. The amount taken up increased with increasing $\mathrm{pH}$ to become equivalent to the deposition of several molecular layers at $\mathrm{pH} 6$. Three mechanisms (acting possibly in concert) could explain this behaviour: (i) deposition of a second molecular layer with insertion of the alkyl side chains of these molecules between the side chains of molecules of the first layer; (ii) penetration of the wall and cell membrane by adsorbed molecules of the monolayer to reach the cytoplasm, thereby vacating binding sites on the cell surface at which further uptake occurs; (iii) (in the region of the c.m.c.), the association of organisms with drug micelles.

The isotherms at $\mathrm{pH} 7 \cdot 0$ and $8 \cdot 0$, at which $\mathrm{DDE}$ was predominantly present as the free amine, were, by contrast, of the $S$ type (Giles et al., 1960). This form is believed to indicate cooperative uptake (West, Carroll \& Whitcomb, 1952). It is therefore proposed that the drug molecules binding initially achieve partial penetration and disorganization of the bacterial walls, leaving vacant sites on the surface and at the same time creating new binding sites. With increasing concentration the walls are penetrated completely and the cytoplasm is reached. The absence of any plateau region from these isotherms suggests that at no point was a stable monolayer established. The higher lipid solubility of the free amine, indicated by the octanol-water partition coefficient, favours this mechanism, since free amine would be capable of penetrating the lipid-rich zones in the wall more readily than would the protonated species. Although there was good correlation between uptake and the partition coefficient, if this factor alone had governed the process then the isotherm would have been a straight line (C type isotherm; Giles et al., I960). Since the uptake at $\mathrm{pH} 8.0$ (at which dodecyldiethanolamine was $2 \%$ protonated) was less than that at $\mathrm{pH} 7 \cdot 0$ (20\% protona- 

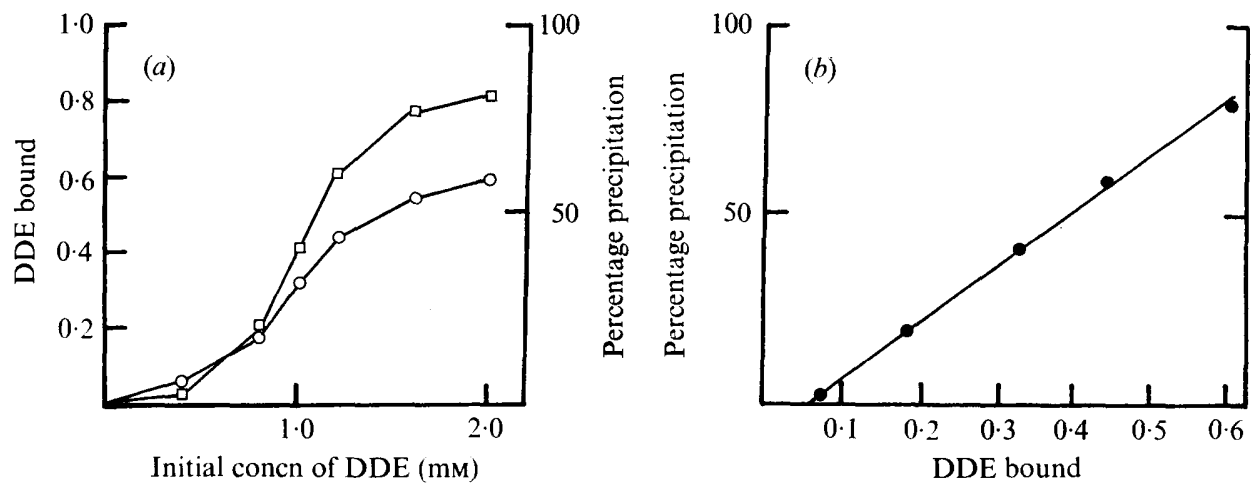

Fig. 5. Precipitation of cytoplasmic material by treatment of cell-free extract of $E$. coli with DDE at $\mathrm{pH} 7 \cdot 0$. (a) Amount of DDE bound by extract $(O)$ and percentage precipitation of material absorbing at $260 \mathrm{~nm}(\square)$ in relation to DDE concentration. (b) Relationship between amount of DDE bound and the percentage precipitation of material absorbing at $260 \mathrm{~nm}$. DDE bound is expressed as $\mu \mathrm{mol}$ (mg dry wt of original organisms) ${ }^{-1}$.

tion), it is likely that even within this $\mathrm{pH}$ range uptake depended to some extent on the presence of protonated molecules, and that the optimum degree of protonation was achieved around $\mathrm{pH} 7$.

Further evidence for cellular penetration was obtained by comparing the uptake of standardized suspensions at $\mathrm{pH} 7 \cdot 0$ with that of envelopes and cytoplasmic extract (Fig. 4). At low drug concentrations the isotherm for the envelope suspension at $\mathrm{pH} 7 \cdot 0$ was of the $\mathrm{S}$ type, indicating a mechanism similar to that for whole bacteria. However, at higher concentrations this isotherm reached a plateau, whereas the isotherm for whole bacteria indicated further uptake. The uptake by whole bacteria was greater at all concentrations than that by the envelopes, therefore penetration of whole bacteria must have occurred throughout the range investigated.

DDE was precipitated from solution in combination with components of the cytoplasmic extract. The extent of the interaction was determined by measuring the absorbance at $260 \mathrm{~nm}$ of the supernatant liquid after removing the precipitate from treated cytoplasm by centrifugation. Up to $80 \%$ of the material absorbing at $260 \mathrm{~nm}$ could be removed from solution (Fig. $5 a$ ) in quantities proportional to the amount of drug bound (Fig. $5 b$ ). Drug binding increased sharply in the range of rapidly increasing uptake by whole bacteria and saturation of isolated envelopes (Fig. 4). This may signify that, once the envelopes had become saturated, further uptake of DDE by whole bacteria proceeded with the intracellular precipitation of DDE and cytoplasmic material.

The outermost region of the wall of $E$. coli is the outer membrane (Costerton, Ingram \& Cheng, 1974) which forms a partial permeability barrier through which any antimicrobial compound acting on the cytoplasmic membrane or other intracellular site must pass (Leive, 1974). The outer membrane contains both anionic residues, e.g. carboxyl groups, to which protonated DDE molecules can bind, and lipid regions which provide sites of attachment for the more lipid-soluble free amine. The surface charge of $E$. coli does not vary greatly over the $\mathrm{pH}$ range $5^{\circ} 0$ to 8.0 , and is only slightly diminished at $\mathrm{pH} 4.0$ (Neihof \& Echols, 1973). It is therefore reasonable to assume that the differences in uptake over the pH range 4.0 to 8.0 were due to changes in protonation and polarity of DDE, and not to changes in the surface charge properties of the bacteria.

The uptake of protonated DDE by $E$. coli in the $\mathrm{pH}$ range 4.0 to 6.0 shows some features which are similar to the uptake of the quaternary ammonium compound cetyltrimethylammonium bromide (CTAB). Salt \& Wiseman (1968) reported that the uptake of CTAB by $E$. coli was biphasic. They suggested that the first phase of uptake corresponds to the 
completion of a monolayer of CTAB molecules on the cell surface, whereas the second corresponds to penetration of the wall. However, the extensive penetration of the wall achieved by free DDE at $\mathrm{pH}$ values above 6.0 suggests that DDE possesses a greater ability to damage both the outer membrane and the cytoplasmic membrane.

As a result of damage to the cytoplasmic membrane by DDE, leakage of cellular components such as $\mathrm{K}^{+}$and nucleotides ensues, resulting in death of the cell (Lambert \& Smith, 1976, 1977); therefore in this respect too the effects of DDE and the quaternary ammonium compounds (Hamilton, I97I; Harold, I970) are similar.

We are grateful to Drs B. Demetriou and W. Mann for helpful discussion and to Mr F. Morsley for assistance given in the preparation of electron micrographs.

\section{REFERENCES}

Corrin, M. L. \& Harkins, W. D. (I947). Determination of the critical concentration for micelle formation in solutions of colloidal electrolytes by the spectral change of a dye. Journal of the American Chemical Society 69, 679-683.

Costerton, J. W., Ingram, J. M. \& Cheng, K-J. (1974). Structure and function of the cell envelope of Gram-negative bacteria. Bacteriological Reviews $3^{8}, 87-110$.

Cummings, M. M., Hudgins, P. C., Runyon, E. H., TAGer, M. \& Lester, C. T. (1953). Tuberculostatic and fungistatic activity in vitro of certain alkyl amines. Transactions of the National Tuberculosis Association, 49th Meeting, pp. 79-85.

Cymerman-Craig, J. \& Diamantis, A. A. (I953). Lipoid-water partition coefficient of some aromatic bases. Journal of the Chemical Society, 1619I62I.

Dawson, R. M. C., Elliott, E. C., Elliott, W. H. \& JoNES, K. M. (1969). Data for Biochemical Research, and edn. Oxford: University Press.

Fieser, L. F. \& FIESER, M. (1959). Steroids. New York: Reinhold.

Fuller, A. T. (1942). Antibacterial action and chemical constitution in long-chain aliphatic bases. Biochemical Journal 36, 548-558.

Giles, C. H., MacEwan, T. H., NakhURA, S. N. \& SMrтH, D. (1960). Studies on adsorption. Part XI. A system of classification of solution adsorption isotherms, and its use in diagnosis of adsorption mechanisms and measurement of specific surface areas of solids. Journal of the Chemical Society, 3973-3993.

Hamiton, W. A. (I97I). Membrane active antibacterial compounds. In Inhibition and Destruction of the Microbial Cell, pp. 77-93. Edited by W. B. Hugo. London: Academic Press.

HaNby, W. E. \& Rydon, H. N. (1947). 2-Chloroalkylamines. I. Preparation and general reactions. Journal of the Chemical Society, 5I3-519.

Hansch, C., Leo, A. \& Nikaitani, D. (1972). On the additive-constitutive character of partition coefficients. Journal of Organic Chemistry 37, 3090-3092.

HAROLD, F. M. (1970). Antimicrobial agents and membrane function. Advances in Microbial Physiology 4, 45-103.
Hugo, W. B. (1967). The mode of action of antibacterial agents. Journal of Applied Bacteriology 30, $17-50$.

LAMBerT, P. A. \& Smith, A. R. W. (1974). Antimicrobial activity of alkyldiethanolamine with particular reference to the effect of $\mathrm{pH}$ upon the uptake of dodecyldiethanolamine by Escherichia coli NCIB8277. Proceedings of the Society for General Microbiology r, 49-50.

LAmberT, P. A. \& Smith, A. R. W. (1976). Antimicrobial action of dodecyldiethanolamine: induced membrane damage in Escherichia coli. Microbios 15, 191-202.

Lambert, P. A. \& Smith, A. R. W. (1977). Antimicrobial action of dodecyldiethanolamine: activation of ribonuclease $\mathbf{I}$ in Escherichia coli. Microbios 17, 35-49.

LEIVE, L. (1974). Barrier function of the Gramnegative envelope. Annals of the New York Academy of Sciences 235, 109-1 29.

NeIHOF, R. \& Echols, W. H. (1973). Physicochemical studies of microbial cell walls. I. Comparative electrophoretic behaviour of intact cells and isolated cell walls. Biochimica et biophysica acta 318, 23-32.

Persianov, Yu. N., Bortovoi, I. M., Tronov, B. V. \& OleINIK, N. N. (1968). N-Alkoxydiethanolamines. Trudy. Nauchnyi Kongress Tomskoe Otdelenie Vsesoyuznoe Khimicheskoe Obschestvo x, 295-297. [In Russian. Abstract: Chemical Abstracts 73 (1970), 55572a].

SALT, W. G. \& WiSEMAN, D. (1968). The uptake of cetyltrimethylammonium bromide by Escherichia coli. Journal of Pharmacy and Pharmacology 20 supplement, I4S-17S.

ScotT, G. V. (I968). Spectrophotometric determination of cationic surfactants with Orange II. Analytical Chemistry 40, 768-773.

Shelton, R. S., van CAMPEN, M. G., Tilford, C. H., LANG, H. C., Nisonger, L., Bandelin, F. J. \& RubenKoenig, H. L. (I946). Quaternary ammonium salts as germicides. I. Non-acylated quaternary ammonium salts derived from aliphatic amines. Journal of the American Chemical Society 68, 753-755.

Smith, A. R. W., Lambert, P. A., Hammond, S. M. \& JEssur, C. (1975). The differing effects of cetyltrimethyl ammonium bromide and cetrimide 
B.P. upon growing cultures of Escherichia coli West, W., Carroll, B. H. \& Whitcomb, D. H. NCIB 8277. Journal of Applied Bacteriology 38, 143-149.

SyKes, G. (1965). Disinfection and Sterilization, 2nd edn. London: Spon.

(1952). The adsorption of sensitizing dyes in photographic emulsions. Journal of Physical Chemistry 56, 1054-1067. 